\title{
Research Paper Economic analysis of pineapple production in Sindhudurg district of Maharashtra
}

See end of the paper for authors' affiliations

Correspondence to : SHILPA MATHEW Department of Agricultural Economics, College of Agriculture, Dr. Balasaheb Sawant Konkan Krishi Vidyapeeth, Dapoli, RATNAGIRI (M.S.) INDIA Email: sagartarang@ rediffmail.com

\section{Paper History :}

Received : 11.05.2017;

Revised : 08.08.2017;

Accepted : 15.08.2017
AbSTRACT : Fruits are nature's wonderful gift to mankind. Pineapple is an important commercial fruit crop with high export value. In this paper, an attempt has been made to study the economic analysis of pineapple production in Sindhudurg district of Maharashtra pertained to the years 2013-16 with a view to analyse resource use pattern, cost and returns and farm business analysis. The study was based on the primary data collected from tenant growers of Dodamarg tahsil in Sindhudurg district. Per hectare physical input utilization pattern indicated that there was higher utilization of inputs such as hired labour, fertilizers and plant protection chemicals. Per hectare cost of cultivation and the net returns amounted to Rs. 588220 and Rs. 993511 for the three years with an overall benefit cost ratio of 2.68. The farm business analysis indicated that the pineapple cultivation was highly profitable in all the three years.

Key Words : Pineapple, Cost, Returns, Resource use, Farm business analysis

How To Cite This PAPer : Mathew, Shilpa,Wadkar, S.S. and Kshirsagar, P.J. (2017). Economic analysis of pineapple production in Sindhudurg district of Maharashtra. Internat. Res. J. Agric. Eco. \& Stat., 8 (2) : 351-356, DOI : 10.15740/HAS/IRJAES/8.2/351-356. 